Article

\title{
Threats to Sustainability of Soil Functions in Central and Southeast Europe
}

\section{Hikmet Günal ${ }^{1, \dagger, *}$, Tayfun Korucu ${ }^{2, \dagger}$, Marta Birkas ${ }^{3, \dagger}$, Engin Özgöz ${ }^{4, \dagger}$ and Rares Halbac-Cotoara-Zamfir ${ }^{5, \dagger}$}

1 Department of Soil Science, Gaziosmanpasa University, Tokat 60240, Turkey; E-Mail: hikmet.gunal@gop.edu.tr

2 Department of Biosystem Engineering, Kahramanmaraş Sutcu Imam University, Kahramanmaras 46100, Turkey; E-Mail: tkorucu@hotmail.com

3 Institute of Crop Production, Szent István University, H-2103 Gödöllö, Hungary; E-Mail: Birkas.Marta@mkk.szie.hu

4 Department of Biosystem Engineering, Gaziosmanpasa University, Tokat 60240, Turkey; E-Mail: engin.ozgoz@gop.edu.tr

5 Department of Hydrotechnics, Politehnica University of Timisoara, Timisoara 300006, Romania; E-Mail: raresh_81@yahoo.com

$\dagger$ These authors contributed equally to this work.

* Author to whom correspondence should be addressed; E-Mail: hikmet.gunal@gop.edu.tr; Tel.: +90-533-738-4759; Fax: +90-356-252-1488.

Academic Editor: Marc A. Rosen

Received: 14 December 2014 / Accepted: 12 February 2015 / Published: 16 February 2015

\begin{abstract}
A diverse topography along with deforestation, changing climatic conditions, long-term human settlement, overuse of agricultural lands without sustainable planning, cultural difficulties in accepting conservative land management practices, and wrong political decisions have increased the vulnerability of many soils to degradation and resulted in a serious decline in their functional capacity. A progressive reduction in the capacity of soils to support plant productivity is not only a threat in the African continent and its large desert zone, but also in several parts of Central and Southeastern Europe (CASEE). The loss of soil functions throughout CASEE is mainly related to the human activities that have profound influence on soil dynamic characteristics. Improper management of soils has made them more vulnerable to degradation through water and wind erosion, organic matter depletion, salinity, acidification, crusting and sealing, and
\end{abstract}


compaction. Unmitigated degradation has substantial implications for long term sustainability of the soils' capability to support human communities and resist desertification. If sustainable agricultural and land management practices are not identified, well understood and implemented, the decline in soil quality will continue and probably accelerate. The lack of uniform criteria for the assessment and evaluation of soil quality in CASEE countries prevents scientific assessments to determine if existing management practices are leading to soil quality improvement, or if not, what management practices should be recommended to mitigate and reverse the loss of soil health.

Keywords: soil health; degradation; land management; erosion; Central and Southeast Europe

\section{Introduction}

Rapid human population growth, along with the spread of technology and culture have significantly increased the rate of natural degradation processes in the pedosphere. Several parts of Central and Southeastern Europe (CASEE) are characterized by severe soil degradation due to accelerated water and wind erosion, nutrient imbalance, depletion of soil organic matter, waterlogging, salinization, contamination, acidification, landslides, soil sealing and compaction by both farm machinery and grazing. Many of these processes cause land abandonment which, in turn, may accelerate degradation processes due to desertification. Abandoned poor agricultural land in Poland constitutes at least 1/3 of all waste land (almost 0.5 million ha) [1]. Both policies and planning instruments for agriculture in many CASEE countries were missing prior to establishing the European Union. Therefore, migration from rural to urban areas and the lack of rural infrastructure development led to an increase in negative anthropogenic influence on soils [2].

The decline in soil quality or degradation of soil, as a consequence of intensive or improper land use, is a problem with ancient roots. Degradation impairs soil quality by partially or entirely influencing one or more of its functions [3]. Although some destructive processes occur naturally, human activity can accelerate the rate of destruction, initially causing a decline in functioning capacity of soils and finally resulting in a loss of the biological production capacity. Therefore, a desert condition is often associated with long-term human habitation in a region [4]. For sustainable development, soils (or soil functions) need to be protected from degradation [5]. Turkey was once the breadbasket for civilization and food production within the region. It has been inhabited since the Paleolithic era, including various Ancient Anatolian civilizations and ancient Thracians [6]. Many of the fertile lands located in semi-arid to semi-humid regions that provided the most favourable sites for the early development of human culture and were once used by archaic civilizations are now buried in debris, because of destructive treatment of the land [4]. Tillage-based agricultural production during those ancient times led to soil degradation resulting in reduced human carrying capacity of the land. Tillage accelerates the destruction of soil organic matter, diminishes microorganism populations, weakens the strength of soil aggregates, and impacts many of the soil-mediated ecosystem functions that ensure, adjust and conserve environmental services. Montgomery [7] concludes that tillage influences soil stability, resilience and quality. He states that the notion of soil quality is referring to 
the soil's capacity to perform three main functions: economic productivity, environmental regulation and aesthetic or cultural value.

Soil quality has been defined by Doran and Parkin [8] as "the capacity of a soil to function, within ecosystem and land-use boundaries, to sustain biological productivity, maintain environmental quality, and promote plant and animal health." Maintaining soil quality is essential to meet growing human needs for sustainable food and fiber production. Unlike air and water, soil is a limited, non-renewable resource that is not readily movable and does not recover from damage as easily as those resources [9]. Accumulation of salts and in particular sodium in soils when irrigation water is applied to land with inadequate or inefficient drainage will result in deterioration of soil physical structure that can restrict crop establishment and growth [10].

As a multifunctional part of the environment, soil is a conditionally renewable natural resource. It is the most important medium for multipurpose biomass production; the integrator and reactor of other natural resources; a natural repository of water, heat and plant nutrients; a substance with a huge buffering and detoxifying capacity for natural and human-induced stresses; a habitat for soil-dependent organisms; and a mediator of biodiversity. Soil resources may be used and conserved at the same time, but the preconditions of soil resilience must be ensured: constant attention and special care are needed to preserve the unique ability of soil resources [11]. Modification of soil physical, chemical and biological properties through tillage has negative impacts on the functioning capacity of soils. The alteration of soil conditions caused by tillage might seem useful in lowering bulk density while increasing porosity and infiltration. However, in the long-term, tillage causes a decline in soil quality [12] that can eventually threaten the sustainability of food and fiber production in agricultural lands. This will result in poverty of rural areas, force people to migrate from rural to urban areas, and increase urban sprawl onto fertile agricultural lands. Urban sprawl is one of the most prominent threats to agricultural lands surrounding industrialized cities. In order to prevent further degradation of ever widening bands of current agricultural land surrounding large cities, farmers have to be convinced that agriculture can be profitable and sustainable if they are willing to adopt conservation tillage and other management practices that are being developed and demonstrated by researchers and the Extension Service.

\section{Historical Changes Contributing to Soil Degradation}

Economic and social situations in the CASEE countries were quite diverse at the end of the 1980s. Political system changes in the former 'socialist' countries had great effects on agricultural production through land privatization, new farm establishments, market liberalization, and attraction of foreign capital. However, there were unexpected socio-economic consequences including a decrease in population, migration of people from rural to urban areas, and an increase in the amount of uncultivated land. Changes in economic and political circumstances, poverty, shortage of production inputs and population growth in CASEE countries are the main causes for a decline in soil quality in agricultural fields [1]. Some of the negative effects of the post-communist land reform in Romania were the excessive fragmentation of farming lands, emergence of a large number of individual farms practicing subsistence agriculture and poor services for agriculture (i.e., support for irrigation, fertilization, and mechanization). All have contributed to severe degradation of soil quality [13]. Secondary but no less important causes of soil quality decline include an aging population, agricultural 
industrialization and climate change. Furthermore, in countries like Romania, improper agricultural water management through intensive land reclamation works (i.e., irrigation and drainage) without considering climate change forecasts or the links between land reclamation and climate change have all contributed to severe degradation [14].

The conventional primary cultivation practices that led to loss of soil functions prevailed until the end of the 1970s and in some CASEE countries until the end of the 1990s. Unfortunately, in countries like Turkey and Romania, conventional tillage is still the main practice applied for crop production. Conventional tillage in many of CASEE countries consists of ploughing in autumn to a depth of $18-30 \mathrm{~cm}$ to control weeds and bury plant residues, and a secondary tillage operation to create a seed bed. Özgöz et al. [15], used the Soil Management Assessment Framework (SMAF) to quantitatively evaluate farmland and pasture management on soil quality of fine, smectitic, active Typic Haplustolls in Turkey. The pasture had never been cultivated, whereas conventional tillage was used on the farmland for approximately 50 years. Quality assessment indicated that soils within farmland were functioning at 71 and 70 percent of their full potential at the $0-15 \mathrm{~cm}$ and $15-30 \mathrm{~cm}$ depth increments, whereas pasture soils were functioning at 73 and 69 percent, respectively. The lowest indicator scores were obtained for total organic carbon (TOC) and bulk density (BD) at both depths, presumably due to conventional tillage, intensive grazing and compaction. Overgrazing by sheep and cattle actually resulted in higher bulk density in pasture and a lower overall soil quality index (SQI) than cultivated areas. A significant reduction in TOC score indicated substantial loss of organic carbon in farmland soils where soil organic matter was inherently high before conversion.

Traditionally, the importance of creating a good seedbed for plants, including the improvement of soil fertility, has been emphasized [16] to producers. From a physical perspective, tillage was regarded as playing a very important role in creating a favorable seedbed. Consequently, a period of several centuries was dominated by this approach and is referred to as the era of crop oriented tillage. Over-estimation of the importance of tillage for crop production resulted in damage to soils that ultimately led to an era of "soil oriented" tillage starting in the mid-1960s. By using soil-preserving tillage practices, soil quality could be protected and all crop requirements could be met by keeping the soil in a good physical and biological condition. In addition to causing less damage, soil oriented tillage also reduced costs of production. Following the recent recognition of increasing climate change effects, new trends are emerging recognizing that tillage also has a climate effect and must also be managed with the aim of reducing greenhouse gas (GHG) emissions through improved soil quality.

\section{Strategies for Overcoming Historical Degradation}

Arable land use systems can be classified into various categories depending on their impacts on the soil, environment, and farmers practices: early low intensity ( 1000s-1800s), conventional ( 1800-1960s, from the first year of deeper tillage), early intensive $(\sim 1960-1980)$, integrated $(\sim 1980-)$, modern intensive $(\sim 1990-)$, modern low intensity $(\sim 1990-)$, and ecological/organic $(\sim 1980-)$. The factors taken into account in their review and appraisal are yield, productivity, crop species, manure application, chemical load, weed control, energy input, equipment level, required expertise, tillage and environmental damage [17]. Soil degradation is considered to be a permanent threat and originated from the first land use systems (Table 1). 
Table 1. Assessment of the land use systems within the CASEE region [17].

\begin{tabular}{|c|c|c|c|}
\hline Land use pattern & Positive to soil attributes & Negative to soil attributes & Long-term consequences $( \pm)$ \\
\hline $\begin{array}{l}\text { Early low intensity } \\
(\sim 1000 s-1800 s)\end{array}$ & $\begin{array}{l}\text { No chemical soil contamination; } \\
\text { Moderated soil diseases; } \\
\text { Moderated deepening of } \\
\text { the tilled layer }\end{array}$ & $\begin{array}{l}\text { Soil compaction; Moderated } \\
\text { decreasing OM resources; } \\
\text { Water and wind erosion }\end{array}$ & $\begin{array}{l}\text { Extending arable area at the } \\
\text { expense of forests, swamps, } \\
\text { etc.; Arable area exposing } \\
\text { to climate threats }\end{array}$ \\
\hline $\begin{array}{l}\text { Conventional } \\
(\sim 1800-1960 \mathrm{~s})\end{array}$ & $\begin{array}{l}\text { Slight chemical contamination } \\
\text { of soils }\end{array}$ & $\begin{array}{l}\text { OM loss due to } \\
\text { multi-ploughing systems; } \\
\text { Soil physical deterioration }\end{array}$ & $\begin{array}{l}\text { Decreasing humus content } \\
\text { of soils; Extending water } \\
\text { and wind eroded area }\end{array}$ \\
\hline $\begin{array}{l}\text { Early intensive } \\
(\sim 1960-1980)\end{array}$ & $\begin{array}{l}\text { Recognizing the threats of } \\
\text { reduction in soil fertility }\end{array}$ & $\begin{array}{l}\text { Declining soil biological } \\
\text { activity due to higher } \\
\text { chemical and physical load }\end{array}$ & $\begin{array}{l}\text { Increasing intensity of soil } \\
\text { physical deterioration and } \\
\text { expose soil to different danger }\end{array}$ \\
\hline Integrated $(\sim 1980-)$ & $\begin{array}{l}\text { Harmony between soil physical, } \\
\text { chemical and biological factors }\end{array}$ & $\begin{array}{l}\text { More soil disturbance to } \\
\text { limit new pests, diseases } \\
\text { and weeds }\end{array}$ & $\begin{array}{l}\text { Improvement of } \\
\text { soil biological and } \\
\text { physical characters }\end{array}$ \\
\hline $\begin{array}{l}\text { Modern intensive } \\
\qquad(\sim 1990-)\end{array}$ & $\begin{array}{l}\text { Moderated chemical load, site } \\
\text { specific physical intervention }\end{array}$ & $\begin{array}{l}\text { Expose to climate } \\
\text { phenomena (silting, } \\
\text { crusting etc.) }\end{array}$ & $\begin{array}{l}\text { Higher input requires } \\
\text { to maintain soil } \\
\text { production ability }\end{array}$ \\
\hline $\begin{array}{c}\text { Modern low } \\
\text { intensity }(\sim 1990-)\end{array}$ & $\begin{array}{l}\text { Soil condition may be } \\
\text { improved in longer period }\end{array}$ & $\begin{array}{l}\text { Soil condition may } \\
\text { deteriorate during } \\
\text { non-hoped wet seasons }\end{array}$ & $\begin{array}{l}\text { Soil productivity affecting } \\
\text { by climate, site and } \\
\text { technology level }\end{array}$ \\
\hline Organic $(\sim 1980-)$ & $\begin{array}{l}\text { Favorable soil biological } \\
\text { activity, great number of } \\
\text { earthworms }\end{array}$ & $\begin{array}{l}\text { More intervention in soil } \\
\text { state requires organic } \\
\text { matter compensation }\end{array}$ & $\begin{array}{l}\text { Ploughing is used as crop } \\
\text { protection method-soil } \\
\text { structure deterioration } \\
\text { seems a real threat }\end{array}$ \\
\hline
\end{tabular}

Tillage has been an important factor of the land use pattern for centuries.Conventional systems include primary and secondary tillage operations used in preparation of a seedbed for a given crop and area. On the other hand, conservation systems combine tillage and planting operations striving to maintain at least 30\% surface cover after planting. Erosion is reduced by at least $50 \%$ in conservation tillage compared to bare soils $[18,19]$. Conservation tillage systems can reduce erosion due to the crop residue left on the soil surface and improve soil conditions for crop growth, while at the same time conserving energy and lowering the cost of farming. Crop residue left on the soil surface is especially effective in reducing evaporation rate, providing plants with nutrients, increasing organic matter levels in the soil, and increasing soil water content by decreasing evaporation and increasing infiltration rate and thus can enhance crop growth [19,20]. Conservation tillage can restore soil structure and improve overall soil drainage, allowing more rapid infiltration of water into soil [21,22]. More recently, providing soil surface protection with residue cover has been more important during the summer, because of intense rainfall and periodic droughts.

In Turkey, conventional tillage methods are dominant as conservation tillage has not yet become a standard practice. However, scientific studies, relevant extension activities and governmental incentives to adopt conservative management practices have increased in the last two decades. The result has been an increased use of reduced tillage in some regions [23].Conservation tillage, however, is mostly practiced at the research level while the government has been employing policies to 
promote the use of direct planters to benefit from conservation tillage system [24]. Considering the disadvantages of intensive farming and the related costs, direct seeding seems more plausible for farmers with fewer plant production problems for Turkish farmers [25].

Agricultural tillage practices in Romania have changed over decades. Conservation tillage, characterized by leaving residues on the soil surface and reduced- or no-till practices have become more popular[26], but according to Mihovsky and Pachev [27], it has also increased the possibility of soil compaction (already a problem in Romania) when compared to conventionally tilled soil. They argue that compaction due to the use of conservation tillage can also increase the possibility of flooding or occurrence of poor drainage in vulnerable areas.

In most CASEE countries, agricultural-induced environmental loading has remained low. In fact, the primary problem is not over-fertilization but rather (based on country reports) poor plant nutrition management.Prior to the years of political change, the predominant fertilization strategy was based on the crop and/or soil manuring with an attempt to maintain a positive nutrient balance in the soil. Fertilizer consumption in the CASEE countries declined markedly between 1990 and 2010, but to meet future agricultural production demand, fertilizer use is expected to increase substantially.

\section{Soil Quality Degradation Symptoms in CASEE Countries}

The primary threat to soil quality in CASEE countries is related to human activities. Within the EU, the main symptoms of reduced soil function have been identified as: (1) decline in OM; (2) erosion; (3) compaction; (4) salinization; (5) floods; (6) contamination; and (7) sealing [3,5]. Some of the symptoms are obviously related to each other and one problem can often create and accelerate another (i.e., compaction can cause and in some cases accelerate soil erosion [28]).

\subsection{Decline in Organic Matter}

Soil organic matter $(\mathrm{OM})$ content is often identified as the most important indicator of soil quality because of its effect on water entry, retention and release, aggregation, wind erosion and nutrient cycling. It protects soil from the erosive forces of wind and raindrop, retards water runoff, provides channels for water to penetrate, increases the water holding capacity of soil and the crop yield $[29,30]$, and provides important buffering and filtration capacities, a rich habitat for soil organisms, and an enhanced sink for atmospheric carbon dioxide. Unfortunately, soil OM is not yet rationally managed for its agronomic, environmental or ecological functions.

A decline in OM began centuries ago and has shown higher levels of decline in three periods: the era of multi-ploughing (in the 1800s), the 1960s, and the 1990s. These three periods are associated with the start of the deeper ploughing, the decade of the early intensive land use, and the first years after land privatization. Loss of OM was greatest in certain soil types, especially dystric Cambisols, Luvisols, Stagnosols and Gleysols. Liming, irrigation, drainage, deep ploughing and removing plant residues by either burning stubble prior to ploughing or gathering the material (e.g., cotton and bushy pasture plants) for firewood also contributed to OM decline. Although there is no data to quantify the original levels of soil organic matter (soil chemical analysis did not begin until the end of the 1880s), recognition of soil deterioration and possible contributing factors can be investigated through classic publications. Symptoms of the soil exhaustion have become apparent since the beginning of the 19th 
century. This phenomenon may account for the perceptible reduction in soil organic matter within arable soils. A 2003 survey of SOC throughout the EU [31]indicated that compared to virgin soil, the decline in organic matter due to long term tillage ranged from $10 \%-50 \%$ for most soils but was even higher for others (Figure 1) based on data from the European Conservation Agriculture Federation [32].

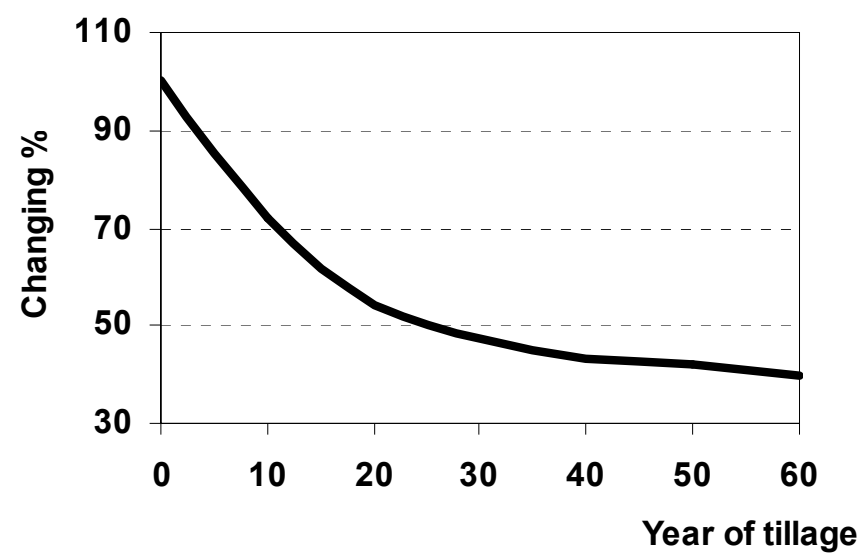

Figure 1. Impact of the years of tillage on changing in organic matter content [32].

The greatest impact on SOM is due to erosion and tillage induced structural degradation. In recent decades, intensive land use and avoiding organic matter recycling (e.g., FYM, stubble residues) both had unfavorable influence on soil processes. As the soil degraded, biomass production was reduced so less was returned to soil and thus the OM content was further depleted [33]. One of the laws of sustainable soil management proposed by Lal [34] states that the rate of restoration of the soil organic matter pool is extremely slow, while its depletion is often very rapid.

Pasture area in Turkey decreased by approximately 47\% between 1938 and 1991 falling from 41-21.8 million hectare (Mha), while cultivated agricultural fields increased by about $80 \%$ from 13.3-24 Mha [35]. Compared to adjacent pasture, conversion to arable lands with the restricted soil depth resulted in significant loss of OM (up to 49\%), decreased in stability of aggregates, reduced mean weight diameter and decreased hydraulic conductivity [36]. Twelve years of continued cultivation of former pasture land in Turkey caused $61 \%$ and $64 \%$ decreases in mean weight diameter for the $0-10 \mathrm{~cm}$ depth and $52 \%$ and $62 \%$ decreases for the $10-20 \mathrm{~cm}$ depth, respectively, when compared to forest and pasture soils. Degradation of soil physical properties due to the loss of OM through cultivation also made soils more vulnerable to erosion [36], because of a decrease in the water infiltration rate that led to increased run-off and soil loss. Montanarella et al. [37] stated that loss of $\mathrm{OM}$, particularly in arid and semi-arid areas, is closely linked to the process of soil erosion. Erosion reduces the organic matter content by washing away fertile topsoil that is vitally important for sustaining soil functions. In Romania, the reduction of organic matter and macro-nutrients content affects more than 3.3 million hectares representing $14.1 \%$ of total country. According to Bireescu et al. [38], the soil organic matter losses, which are caused by the removal of the topsoil, range between $45 \%$ and $90 \%$ of the total organic matter pool in the soil. At the country level, SOM losses are estimated at 500,000 tons per year.

Stubble that was maintained on soil surface, especially in the long-term, increases soil organic matter content, enhances aggregate stability of soils, and provides soil and water conservation [39]. 
Monoculture farming and stubble burning are thought to be the major causes of low organic matter content of soils in Turkey. Stubble burning increased with double-cropping that increased rapidly following the introduction of machinery into farming operations in the 1960s. Burning stubble is perhaps the most controversial crop residue management option. There are advantages to burning, but some of the perceived advantages are not as great as some believed [40]. Stubble burning is important in assisting normal tillage operations reducing or removing the vegetative cover from the soil surface. Burning has also been used as a substitute for herbicides and pesticides in the control of weeds, pests and diseases [39,41]. In minimum or zero tillage systems, burning is often used as means of land clearing to prepare the field for seeding [42]. However, maintaining plant residue on the soil surface is favorable for protecting the soil against wind and water erosion. Burning of stubble removes the entire beneficial plant residue and leaves the soil surface bare and consequently unprotected from raindrop impact and an increased erosion risk.

\subsection{Soil Erosion}

Soil erosion is one of the major and most widespread threats on soil quality. Inappropriate soil management practices led to physical degradation of soils and are major causes for water and wind erosion [43]. Physical degradation of soil may be recognized as the loss of soil structural stability and ability to resist the destructive impacts of wind and water. Structural degradation can be observed both on the surface, where thin crusts may occur, and below the surface when compacted zones form in or below the ploughed layer. The absence of aggregate resistance to disintegration reduces water infiltration and increases runoff and erosion rates[44].Wind or water erosion occurs and is a problem in agricultural lands within almost every CASEE country; even those with flat topography such as Lithuania or the other Baltic states [1]. Soil erosion occurs in vast areas of Ukraine, with 41\% (17 million ha) of agricultural land having been characterized as being subjected to water and wind erosion in 1996 [9]. In the Balkan Peninsula, particularly in Bulgaria and Romania, around $40 \%$ of land is affected by soil erosion [45]. According to Debicki [1], in some of these countries (e.g., Bulgaria, Romania, Albania, Slovenia, FYR of Macedonia, and Georgia), water erosion is very severe and may ultimately lead to desertification.

Soil erosion, mainly due to water and to a lesser extent wind, is still the most important degradation process in most CASEE countries. It has resulted in shallow soil depths,loss of most fertile topsoil and organic matter from eroded surfaces,and irreversible loss of natural farmland over time-scales of tens to hundreds of years [46]. Even where soil is deep and loss of the topsoil is often not apparent, the effects are nevertheless potentially very damaging to sustainability. The rate of erosion is sensitive to climate and management practices, as well as to conservation practices applied at the farm level. Sauerborn et al. [47] indicated that detrimental impacts of soil erosion are anticipated to increase, since climate change is expected to influence the characteristics of rainfall in ways that might increase the intensity of water erosion in central Europe.

In addition to inherent soil properties (e.g., slope and texture), unsustainable agricultural management practices such as forming large fields with no anti-erosion protection before the change in political systems, growing wide-row crops (e.g., maize or sunflower) on sloped fields, and overgrazing are also major causes of erosion. Deforestation and farming in uplands and mountains, overgrazing, use of 
heavy machinery, excessive irrigation of vulnerable agricultural fields, and poverty also result in severe damage to both land and permanent plant cover. Converting natural vegetation cover to field crops requires mechanical soil cultivation that intensifies the erosion [1].

In Romania, more than $40 \%$ of the total agricultural area is situated on the slopes higher than $5 \%$. Because of their soil characteristics, the main problem Romanian agriculture faces in the hilly areas is soil erosion. Almost 5.3 million hectares of agricultural land are vulnerable to surface and depth erosion as well as to landslides. Water erosion is considerable on about 3.5 million hectares of this area. Approximately $55 \%$ of the 4.8 million hectares of pasture and meadow have been negatively affected by erosion and landslides due to inappropriate management. The areas affected by water erosion, which includes agricultural lands, forests and the unproductive areas on slopes, are as follows: slight erosion-46.3\%; moderate and high erosion - 41.5\% and severe to excessive erosion - $12.2 \%[48,49]$. In southern Romania, soil erosion has increased because forest belts have been destroyed, droughts are becoming more frequent, and crop growth is often poor because there are very few irrigation systems.

Deforestation, conventional tillage practices and improper irrigation management have led to increasing rates of soil erosion for a long time in Turkey [50]. Continuing loss of soil functions is now threatening some of the country's most fertile agricultural fields. Although not located within a desert belt per se, improper agricultural practices led to degradation of agricultural fields and put many regions of Turkey at the risk of desertification. Furthermore, with $46 \%$ of the land area having slopes of $40 \%$ or more, many agricultural practices are complicated and erosion is easily increased.

Overall, $59 \%$ of the agricultural land, $64 \%$ of rangeland and $54 \%$ of forestland are subjected to erosion in Turkey, and approximately 180 million tons of sediments are transported to seas and lakes every year. Aykas et al. [51] indicated that sediment lost by erosion is equal to losing $25 \mathrm{~cm}$ of soil from 400 thousand hectares land. This soil loss is an even greater problem considering the political instabilities of neighboring countries such as Syria and Iraq that have been continuing for nearly four decades. Turkey now has to feed almost two million refugees in addition to the 77 million residents of the country. Therefore, any decline in soil quality due to severe erosion and consequent decline in agricultural productivity increases food security risks for Turkey.

Wind erosion is common in the plains of the arid and semi-arid climatic regions, as well as on sandy and silty soils within other CASEE countries. Wind erosion occurs throughout the year on bare lands, and mainly in the spring and summer months on the overgrazed rangelands and over-cultivated/tilled soils. Avci et al. [52] reported severe wind erosion in winter months, especially during the Lodos-south wind in Central Anatolia of Turkey. Lack of plant cover on rangelands and low organic matter content of arable lands are the major causes of wind erosion. In Turkey, wind erosion has not been considered to be as important as water erosion since it is generally confined to special areas such as Karapinar-Konya, Incesu-Kayseri [52], Aralik-Igdir, and coastal regions in Mediterranean and Aegean Sea (Figure 2). 


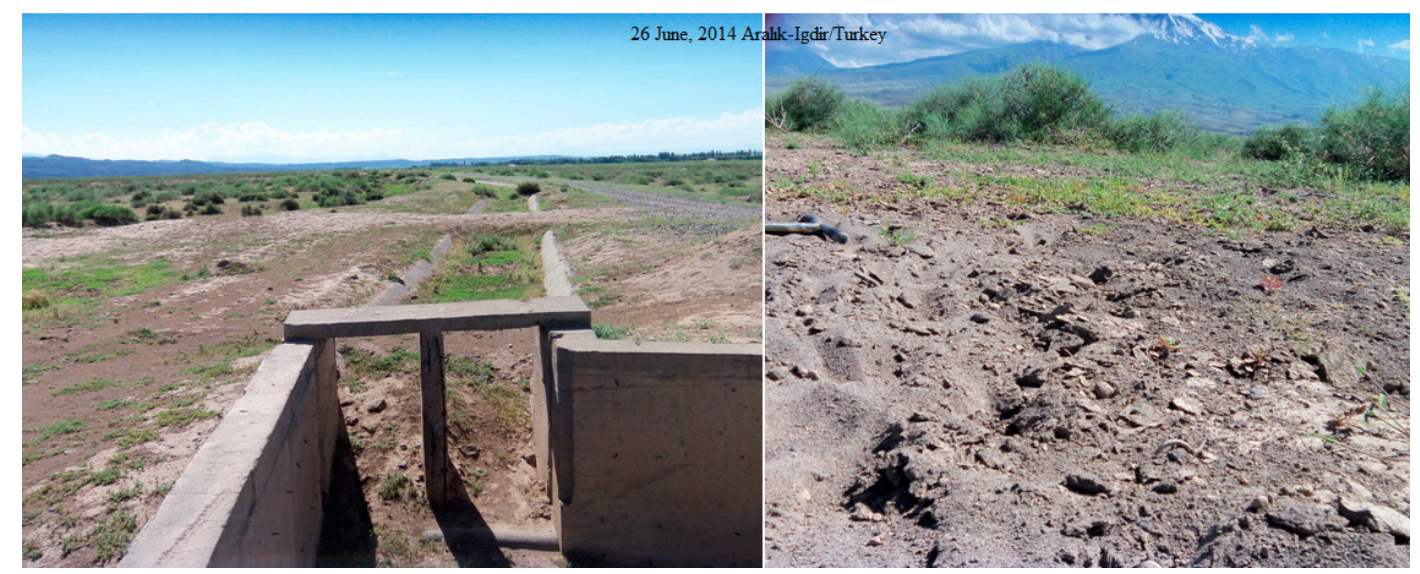

Figure 2. Severe wind erosion, sediments filled the irrigation channel in Aralik-Igdir/Turkey.

Wind erosion is site-specific, especially for the southern part of Romania. The absence of irrigation and the uncontrolled deforestation of protection belts accelerated the northward extension of desertification-affected surfaces and movement of sand dunes. It has also been conducive to depletion of arable-land productivity and, in time, abandonment of those lands [13].

The functions of soils, mainly biomass production, crop yields due to removal of nutrients for plant growth, and soil filtering capacity due to disturbance of the hydrological cycle (from precipitation to runoff) are decreased or totally lost by removal of soil [9]. The estimated area (Table 2) damaged by water erosion calls attention to the need for prevention and alleviation. In the past, loss of productivity was compensated for by installing modern irrigation systems and applying additional mineral fertilizers, so that the impact of the erosion did not appear on time [9]. Nowadays, however, anti-erosion measures must be included in land management plans. Increasing areas of permanent grasslands in hilly and mountainous regions also represent a positive trend toward reducing soil loss.

\subsection{Soil Compaction}

Compaction is one of the most common forms of soil physical degradation which can cause a serious reduction in water penetration and seedling emergence. Soil compaction has been described as one of the five threats to sustained soil quality by the EU Soil Framework Directive. Where crop production has been severely affected by compaction of arable soils in many of CASEE countries, a primary cause has been an increase in field traffic.Globally, more than 68 million ha of land are classified as compacted, with $4 \%$ being associated with anthropogenic soil degradation [53]. In Europe alone, compaction accounts for about $17 \%$ of the total degraded area [54].

Soil compaction represents damage of several soil physical properties, including the breakdown of soil structure, decreased loosening, limited water transport and consequently higher risk for water erosion and drought stress. Soil compaction also negatively impacts other soil processes and can have a range of negative consequences depending upon the inherent soil properties, bearing capacity, moisture condition, relief, field patterns, and applied technologies such as irrigation, fertilizer application, and many other factors [1]. Allen [55] reported that compaction decreases macro porosity and hydraulic conductivity of soils which increases the susceptibility of soils to erosion. Soil compaction results in high mechanical resistance to root growth in a compact dry soil and poor aeration in a compact wet 
soil (Figure 3) [56]. Both natural and induced compaction can occur because of a high content of fine clay- and silt-sized particles and may be caused by either drying out or being covered by water. Traffic induced compaction is caused by heavy machinery and frequent loading on wet soils and is most common between cultivated and undisturbed layers. Under the less favorable economic conditions of CASEE countries, tillage-induced soil compaction (plough or disk pan) occurs more frequently than the traffic-induced variant. Overgrazing can also induce crust formation by surface compaction of wet or moist soils and mechanical destruction of the surface soil aggregates [57]. In Turkey, low organic matter and high clay content often leads to formation of a dense plow pans. Çarman [58] noted that annual yield losses due to soil compaction in Turkey were over one billion U.S. dollars (\$). Furthermore, compaction can also accelerate other threats such as wind and water erosion [28].

Subsurface soil compaction occurs as a result of the forces applied when agricultural machineries are used on the field [56]. Deep soils with less than $25 \%$ clay content are the most sensitive to subsoil compaction [59]. In contrast to the compaction of surface soils, subsurface compaction cannot easily be reversed and may last longer until broken by a ripper [60]. In many CASEE countries, compaction became a very serious degradation agent as the size and weight of farm machinery increased. For example, since 1955 the mass of tractors and tillage implements have increased by $68 \%$ and $200 \%$, respectively, in the Czech and Slovak Republics [1].

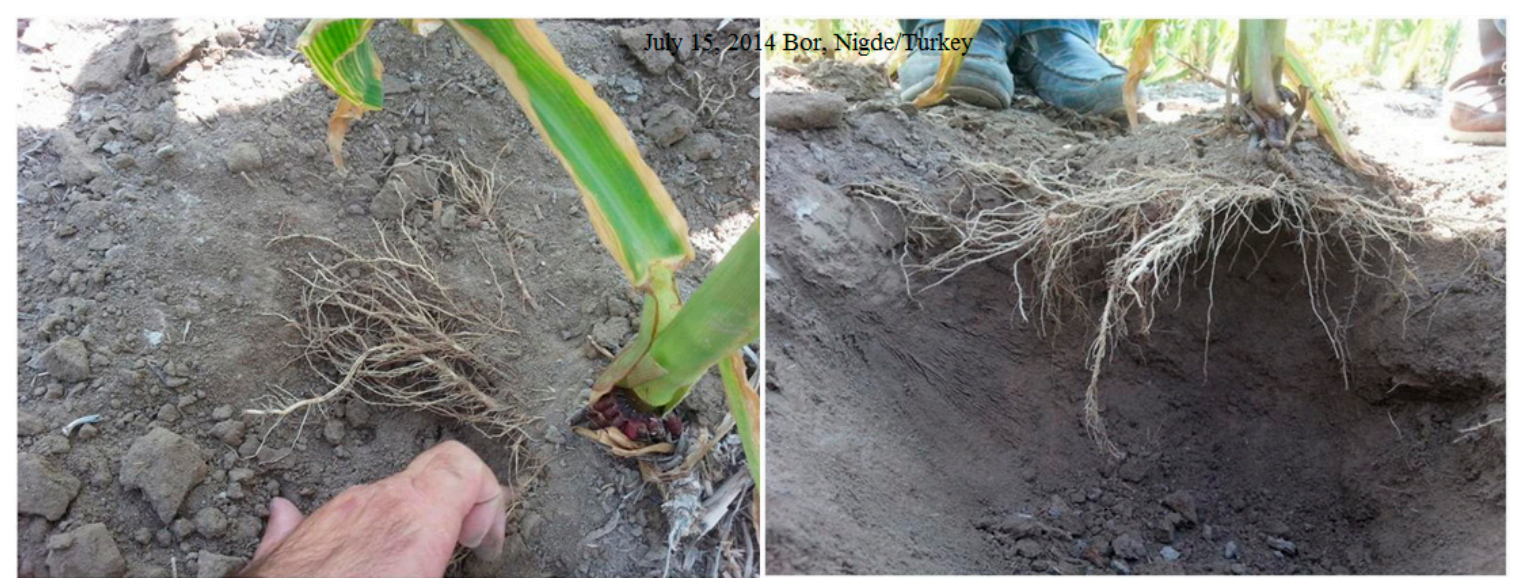

Figure 3. Subsoil compaction severely constrains root growth.

Soil compaction and crusting are most prevalent in the plains region of southern and western Romania, where use of heavy machinery is widespread. Unfortunately, farmers in many CASEEcountries are not aware of the seriousness of subsoil compaction. Restoring drainage, increasing plant nutrition, and improving irrigation systems can sometimes mask the detrimental effects of subsoil compaction on crop production, but those temporary solutions for preventing yield reduction due to compaction often increase expenses for farmers and contribute to environmental problems due to increased use of water and nutrients. Sustainable agricultural production with reasonable management practices requires no subsoil compaction [61].

\subsection{Salinization}

Soilsalinization occurs in areas with saline soils such as the solontsak, solonetz, salinemeadow, and saline chernozems. Itis also a local risk if temporary water logging occurs and brings excess salt from 
deeper layers to the surface.One cause for salinization is irrigation which is vital for agricultural production in arid lands, but with improper management (i.e., lack of drainage)arid land irrigation can negatively impact soil quality through salinization and alkalinization [57]. Salt-induced land degradation is a major drawback to optimal functioning of soils in arid and semiarid regions of CASEE countries. For example, in Romania 4\% of the total agricultural land was affected by salinization in 2002. Inappropriate water regulation, land use changes (conversion to from pasture to arable) deep ploughing, disturbance of deeper soil layers, and irrigation (without proper drainage systems) can exacerbate the salinization problems. Low amounts of precipitation, dry conditions and very high temperatures during summer seasons, topographic properties and parent material, along with wrong (mainly water) management practices, are the major causes.

Salinization and waterlogging are serious problems, especially in areas where large but poorly managed irrigation systems were constructed. Applying excess irrigation water in the absence of a well maintained drainage system may cause the water table to rise and can also result in an increase in secondary soil salinity. To avoid worse effects, strict land use (e.g., avoid deep ploughing) and water management (e.g., no irrigation, using good quality irrigation water,and keeping the water table down) practices must be followed. Intensive tillage of saline soils in arid regions will destroy aggaegates, increase the capillary rise of salts to soil surface and eventually leave soils vulnarable to wind erosion (Figure 4).

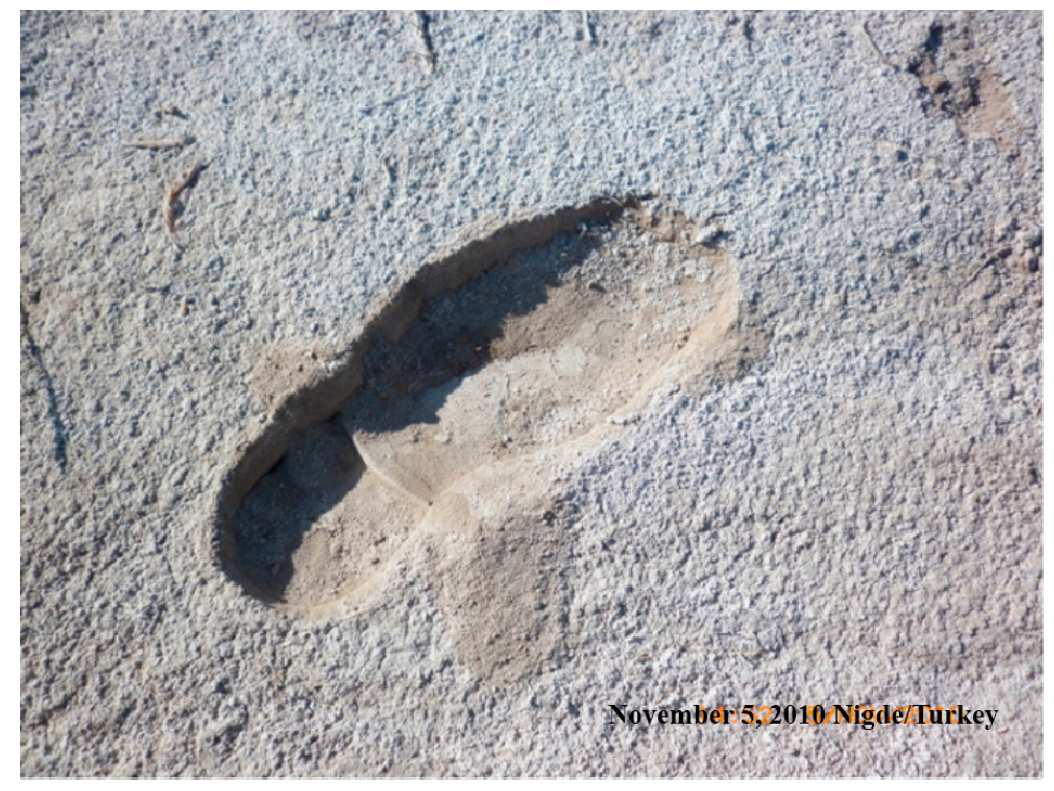

Figure 4. Intensive tillage of saline soils in arid soils increases capillary rise of salts to soil surface.

Unsustainable irrigation practices and inappropriate water management at the farm-level stimulates raising of groundwater and contributes to salt accumulation, particularly in irrigated fields of arid and semi-arid regions [62], and eventually causes salt-induced land degradation. The potential of economically irrigable agricultural lands in Turkey is about 8.5 million ha, of which 4.9 million ha are now irrigated. The government has initiated many projects to expand the irrigated area, strengthen the economy, and meet a growing food demand based on agriculture [62]. The Southeastern Anatolia Project, commonly referred to by its Turkish acronym "GAP", is about to be completed as a large integrated water resources development project in the semi-arid Southeastern region of Turkey. 
The project includes 22 dams in the upper Euphrates-Tigris Basin, and aims to provide irrigation for 1.7 million hectares of land. However, salinity is a major problem in the GAP region, and in particular in the Harran Plain which was first opened for irrigation in 1995. Prior to excessive and uncontrolled irrigation, an insufficient and uncared for drainage system, and an increase in the groundwater level caused by the improper irrigation management practices [63] have all contributed to the problem.

Tillage can be used to improve soil permeability in saline soils, but if it is not properly practiced a compacted plough layer might form and salts will be accumulated above it and potentially bring salts even closer to the soil surface [64]. Timely and convenient monitoring and assesment of soil quality will help guide adoption of corrective mesures to control the salinity that might otherwise threaten the sustainability of crop production. Minimum soil disturbance at a shallow depth is recommended for seedbed preparation in saline soils. Salts leached to the lower part of the soil profile by winter snow melts can be returned to the surface by deep spring tillage. Thus, deep tillage operations on saline land can unnecessarily increase surface salt concentrations [65], and should not be used unless they are needed to ameliorate subsurface compaction.

In Romania, salinization is primarily a natural process, but some poorly applied, intensive land improvement works, such as embankment, drainage and irrigation, have aggravated the problem. Currently, salinization and sodification problems affect less than 600,000 ha of land, and occur mainly in the eastern part of the Romanian Danube Plain and in the Western Plain. In 1989, Romania had more than 3 million hectares of irrigated land and another 3 million hectares of land with adequate drainage systems. By the end of the 1990s, all these projects had been severely degraded, leaving many areas without any cover against extreme drought or intensive precipitation. By 2006, Romania irrigated only $3 \%$ of the overall managed agricultural land and had suffered a decrease in cereal grain output of $35 \%-40 \%$.

\subsection{Flooding}

Localized flooding is a serious problem, associated with extreme rainfall and unpredictable rainy periods. The frequency of floods seems to have increased over the last decade in all CASEE countries, maybe in response to global climate change.

In 2005, the surface exposed to flood danger in natural regime of flow was up to $30,000 \mathrm{~km}^{2}\left(3500 \mathrm{~km}^{2}\right.$ representing agricultural areas), representing about $13 \%$ of the Romanian territory. Romania was severely affected by several floods in recent years that resulted in some important arable areas being no longer suitable for agriculture. An important factor that increased the severity and impact of the floods was that several pumping stations associated with land drainage systems were no longer functioning properly. The drainage canals which were not properly maintained together with an underestimation of pumping stations discharge capacities contributed to long-term stagnation of water from floods and implicitly to land degradation. Several other factors have also contributed to increased flooding problems. These include: (1) a reduced capacity in minor flow paths which in Romania are exceeded about $30 \%-50 \%$ of the time; (2) various construction projects that divert overflow in meadows; (3) abundant rainfall which often exceeds the 20-40 ratio between maximum flood discharge and average discharge; (4) increased hillside runoff; (5) inadequate maintenance of flow paths; (6) improper bridge construction and maintenance that includes obtrusion of bridge sections 
with floats, clogging of canals, inadequate maintenance of gutters in most villages, under dimensioning of bank requirements and cutting large areas of forests; and (7) an increase in natural maximum flood discharge due to long banking without measures concerning to take over these effects[66].

As most high fertility soils are located in floodplains, they are also affected by the floods, through compaction, alluvial deposits, and under certain circumstances, heavy metal pollution. Experts from academia and land reclamation have issued a disastrous scenario for agriculture in the western part of Romania: without rapid intervention inland improvements, floods will cause Romania to lose more than one million hectares of arable land in the Western Plain. Flash floods, which are specific to hilly areas and have been a main factor causing massive deforestations during recent years, can also cause significant land degradation, especially when they are coupled with other phenomena such as landslides, even though they usually affect a relatively small area.

An indirect factor of land degradation due to flooding is represented by political involvement in flood management. The current land reclamation system in Romania, which is based on embankments, drainage and floods, has in recent years passed through a series of perpetual reorganizations making it very unclear what purpose these actions are intended to have. Currently, the National Administration of Land Reclamation is reorganizing and has resulted in massive layoffs with a severe negative impact on maintaining and operating the existing flood management infrastructure. There are numerous examples in which interventions to restore flood defense works were limited to simply recovering the affected works and not according to the physical condition and their continued degradation. Insufficient staff and funds made impossible for maintenance and repair of embankments, dams, channels, and culverts.

\subsection{Soil Contamination}

Soil contamination is an important threat in the CASEE contries due to rapid industrialization and urbanization which often results in soilsbeing used for the disposal of waste products. Fortunately, pollution with heavy metals and radioactive nuclides has a very local character, so large territories of the CASEE countries are suitable for producing environmentally clean products. High competition of soil and land for different uses often causes contamination problems to be particularly high in densely populated areas [9]. The results of 40,000 soil analyses from all over Poland indicated that $79 \%$ of the soils had heavy metal concentrations at background levels while $18 \%$ had concentrations that were slightly over threshold levels. Less than $1 \%$ of the soils ( $2.3 \%$ of agricultural land) were polluted with heavy metals. Agricultural production that does not directly affect the food chain should be performed on these lands [67]. Muranyi [68] reported that results of monitoring heavy metal pollution in Hungary were similar to those reported for Poland. Heavy metal pollution was encountered in only certain hot spots, but soil acidification and soil erosion problems were noted throughout the country. The case for pollution of soils with heavy metals in Czech Republic was also similar to other CASEE countries with high heavy metal concentrations generally being associated with long term industrial emissions [69]. Soil degradation and soil pollution show a manageable rate in some countries (e.g., Czech Republic, Hungary, Slovak Republic), but cautious monitoring and control of the threatening factors need to be continued. The buffering, filtering and transforming functions of soils are mostly affected by local and 
diffuse contaminates. Soils can absorb toxic metals without harm up to a critical point, but loadings over the buffering capacity can result in a release of the substance back to the environment [9].

Acidification, both natural and anthropogenic, is the most widespread type of soil contamination in some Western and Central European countries, with especially large areas having been identified in Poland and Ukraine. Under acidic conditions, exchangeable base cations ( $\mathrm{Ca}, \mathrm{Mg}, \mathrm{K}$, and $\mathrm{Na}$ ) are highly mobilized and leached from soil profile. This leads to a depletion in buffering capacity of soils. The $\mathrm{pH}$ of soils will start to decline and with increasing acidity, ions such as aluminum are mobilized. Higher concentrations of aluminum are toxic to most plants. Acidification also mobilizes heavy metals that were accumulated and bound in the soil under higher $\mathrm{pH}$ conditions [1].

\subsection{Soil Sealing}

Sealing means an irreversible loss of soil multi functionality as a consequence of the competition between their use for infrastructure development versus biomass production. Reviewing the CASEE country reports it seems that the area affected by surface sealing has increased at an average annual rate of about 6000-10,000 ha/year for the last two decades. Since approximately 2010 , the total area under agriculture has remained relatively stable because the new economic situation has resulted in less investment in industry and only moderate deforestation. Soil degradation due to urbanization and industrial development in most of the Central and Eastern European countries has significantly increased, due to recent population shifts and a more extensive urban pattern [9]. Sealing is particularly apparent in coastal zones, where urban and recreation areas, agriculture, industry, commercial activities and tourism are all concentrated, and in many cases, in competition for the same land area. Soil sealing in Romania between 1989 and 1994 increased almost 19\% [70]. Based on a 2012 report published by the Institute of Regional Development Planning at the University of Stuttgart, $45 \%$ of the land area in Hungary was sealed. In contrast, only $20 \%$ and $26 \%$ of the urban land was sealed in Romania and Estonia [70].

Sealing of soils through urban and industrial development, such as the construction of roads, houses, industrial premises, and sporting facilities in Turkey began in the 1950s and accelerated through the 1960s due to the lack of legal enforcement to prevent conversion of agricultural lands, unplanned industrial sprawl upon agricultural and natural areas, and increased population growth [50,72]. The most striking change in demographic structure of Turkey from 1927, when the first consensus of the Turkish Republic was made, to 2011 was the high population increase in urban regions and the decrease in rural areas. Urbanization caused particularly intensive use of arable land around cities. According to the 1927 census, $75.8 \%$ of Turkey's population were living in rural areas and $24.2 \%$ in urban areas. In contrast, the 2011 census showed $23.2 \%$ of the population living in rural areas and $76.8 \%$ living in urban areas.

The severity of sealing is even more complex than the simple loss of land, since the growth of many urban regions often affects high quality soils (Figure 5). Fertile soils around rivers and river deltas are mainly occupied by cities, and valuable land is therefore lost to food production [71]. The occupation of agricultural lands by settlements and commercial and industrial facilities has reduced the productivity of the agricultural sector, while at the same time, increasing the likelihood of floods. 
Occupation of high quality land for settlements and industrial purposes in Turkey has almost reached 172,000 ha [72].

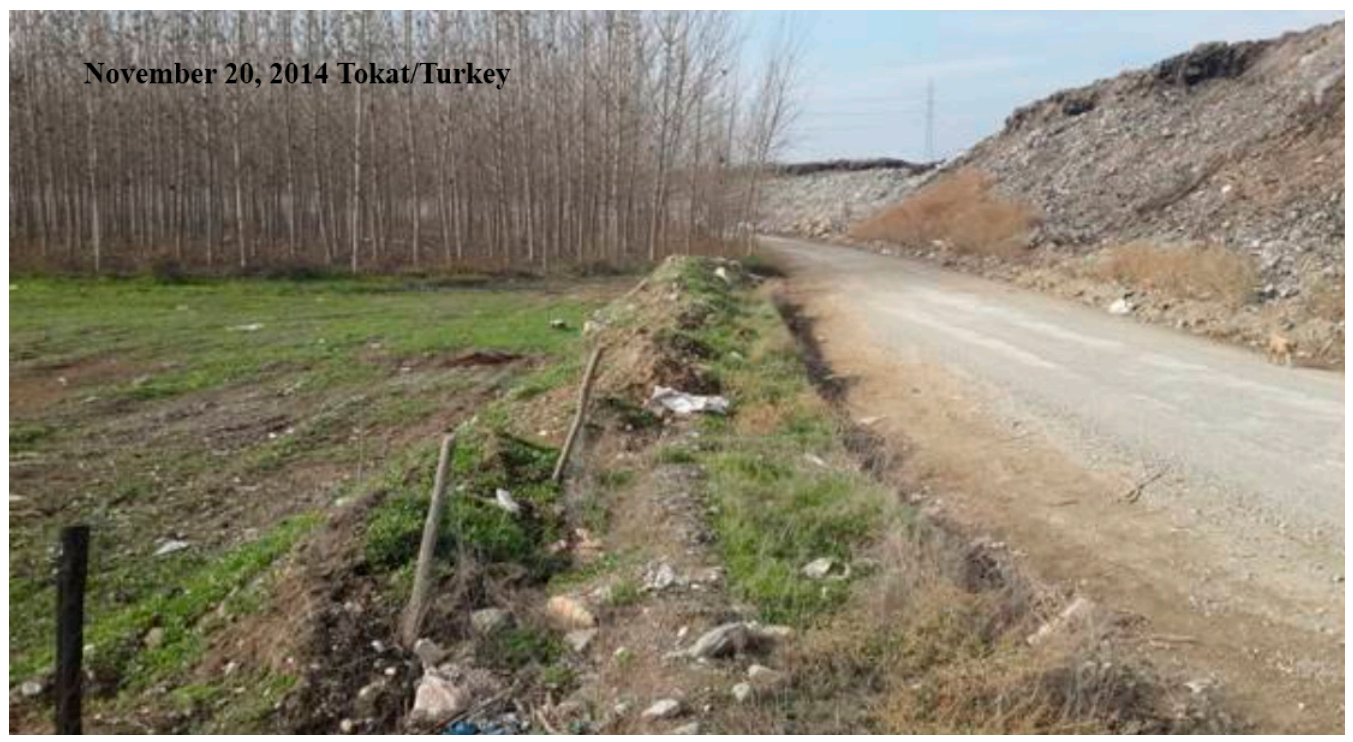

Figure 5. Open dumping of municipal wastes at the edge of agricultural fields in Tokat Province of Turkey.

Table 2. Percentage of agricultural land affected by natural and human-induced soil degradation in selected countries.

\begin{tabular}{ccccccc}
\hline $\begin{array}{c}\text { Selected } \\
\text { countries }\end{array}$ & $\begin{array}{c}\text { Agricultural } \\
\text { land area } \\
(\mathbf{1 0 0 0} \text { ha) }\end{array}$ & $\begin{array}{c}\text { Soil } \\
\text { compaction }\end{array}$ & $\begin{array}{c}\text { Temporary drought/ } \\
\text { water-logging effects }\end{array}$ & $\begin{array}{c}\text { Wind } \\
\text { erosion }\end{array}$ & $\begin{array}{c}\text { Water } \\
\text { erosion }\end{array}$ & $\begin{array}{c}\text { Decline in } \\
\text { OM \% }\end{array}$ \\
\hline Albania & 699 & 36 & $? / 18.5$ & no data & 50 & $0-35$ \\
Bulgaria & 5123 & 47 & $40 / 35$ & 29 & 72 & $10-40$ \\
Croatia & 3220 & $25-35$ & $35 / 25$ & 10 & 35 & $\mathrm{~F}$ \\
Czech Republic & 3101 & $28-34$ & $31 / 27$ & 33 & 14 & $\mathrm{~F}$ \\
Hungary & 5585 & $30-35$ & $27 / 23$ & 24 & 39 & $\mathrm{~F}$ \\
Poland & 18,512 & $20-25$ & $16 / 24$ & 28 & 28.5 & $\mathrm{~F}$ \\
Romania & 14,714 & $5.6(\mathrm{t})$ & $48 / 26$ & $1.6(\mathrm{t})$ & $26.4(\mathrm{t})$ & $14(\mathrm{t})$ \\
Serbia & 5109 & $\mathrm{~F}$ & $35 / 30$ & 13 & 33 & $10-37$ \\
Slovakia & 2466 & 28 & $\mathrm{~F}$ & 6.5 & 43.3 & $\mathrm{~F}$ \\
Slovenia & 480 & $\mathrm{~F}$ & $39(\mathrm{t}) / 23$ & $23(\mathrm{t})$ & $44(\mathrm{t})$ & $\mathrm{F}$ \\
Turkey & 28,050 & $\mathrm{~F}$ & $\mathrm{~F}$ & 0.65 & 87.9 & $\mathrm{~F}$ \\
\hline
\end{tabular}

Note: $(\mathrm{t})$ : from total area; $\mathrm{F}$ : it was found, but not determined.

\section{Other Human Induced Soil Threats in the CASEE Countries}

\section{Managing Crop Residues}

Crop residues are very important for soil conservation. From the 1800s until the 1970s, crop residues were managed primarily by using tillage to create suitable soil conditions, often with fine 
structure, for plant germination, emergence and growth. As discussed previously, overestimation of crop requirements for tillage have likely contributed to the deterioration in soil quality [17].

Recently, attention has again been focused on crop residues as a potential source of "bio-energy" [34]. The challenge is balancing this new demand for crop residue with the traditional uses that are important for soil conservation. Currently, farmers either burn the stubble and residue or leave it on the field surface and plant through it using minimum or no-till practices to incorporate some or all of it into the soil [40]. Surface residue provides protection during the summer and is indisputably important for water conservation in Eastern, Central, and Southern Europe. Crop residues are also being recognized for their ability to buffer climate-induced damage that is being observed more frequently throughout the region during and outside the growing season. Furthermore, although the amount of summer rainfall has been decreasing, the rain storms have become more frequent and devastating. Soil resources are being degraded by the kinetic energy associated with those storms. For example, a $25.4 \mathrm{~mm}$ ( $1 \mathrm{inch}$ ) rainfall event applied uniformly across a 0.4 ha ( 1 acre) surface delivers a force of 2.7 MPa. This amount of energy hitting bare soil in the fields without any plant residue will cause a breakdown of soil aggregates, increase the potential for sealing and make the fields more susceptible to water and wind erosion. Having crop residues on the surface to absorb this energy will prevent degradation of the soil aggregates [51].

Soils deprived of their protective straw are also increasingly exposed to summer climate stress. Crop residues are thus needed to not only keep the soil in place but also to alleviate heat stress and reduce evaporative water loss [74,75]. In addition to crop residues per se, green manure mulch, chemically treated weeds, and volunteer weeds can also provide protective surface for soils. Where the crop residue is left on the soil surface, the level of protection is first affected by the ratio of the cover, and later by the mode and quality of stubble tillage. Table 3 shows that the amount of soil removed from field was significantly reduced as the amount of crop residue on the soil surface increased [76]. Similarly, Kalmár et al. [77] cited Schertz [78] who stated that soil conserving tillage is characterized by having at least $30 \%$ cover ratio after sowing.

Figure 6 shows surface soil that has no residue cover in a typical fallow-wheat system in Central Anatolia. This widely used system is incompatible with the conservation agriculture concept due to frequent tillage operations for weed control and seedbed preparation during the 16 months of fallow. Even after planting the crop (wheat, barley or rye), the fields have no residue cover to protect them from wind and water erosion during the initial part of the growing period [52].

Table 3. The relationship between crop residue on soil surface and soil loss [76].

\begin{tabular}{cccc}
\hline Crop Residue tons/ha & Runoff \% & Infiltration \% & Soil Loss tons/ha \\
\hline 0.00 & 45.0 & 54 & 13.00 \\
0.63 & 40.0 & 60 & 7.50 \\
1.25 & 25.0 & 74 & 2.50 \\
2.50 & 0.5 & 99 & 0.75 \\
5.00 & 0.1 & 99 & 0.00 \\
10.00 & 0.0 & 100 & 0.00 \\
\hline
\end{tabular}




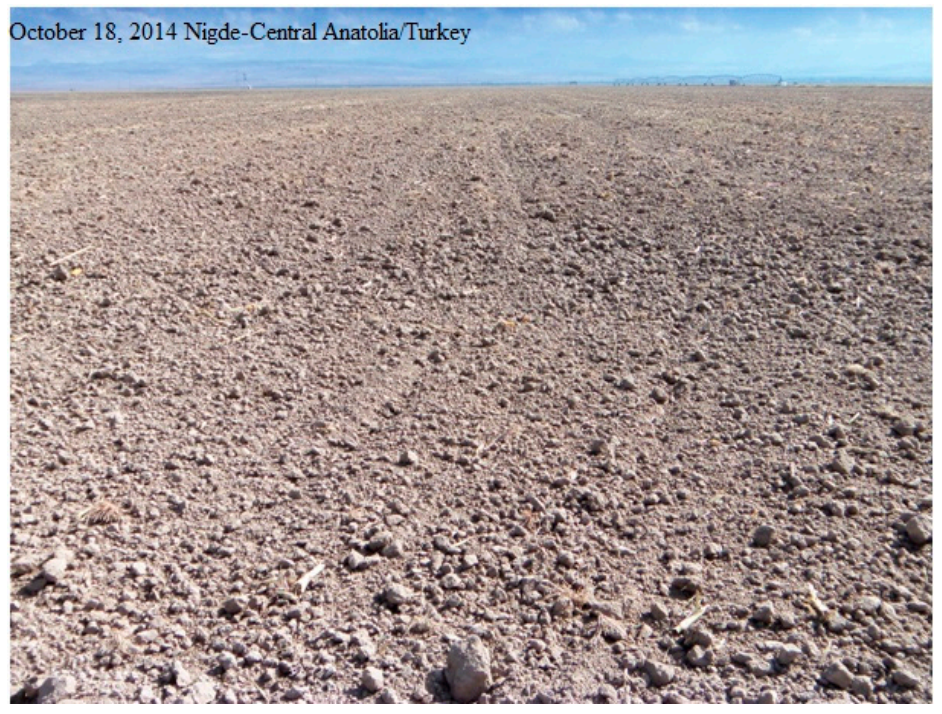

Figure 6. Fallow-wheat system applied in Central Anatolia.

\section{Conservation Farming for Achieving Sustainable Soil Systems}

Soil deterioration has occurred for centuries primarily due to "conventional" soil management. When the processes causing deterioration of soil quality are traced and controlled, both soil-use and soil quality are sustainable [5]. The concept of sustainability has environmental, economic and social aspects as well as an institutional dimension. Therefore, processes affecting all of these issues should be taken into account to maintain soil health.

Beginning as early as the $1860 \mathrm{~s}$, the practice of ploughing to depths exceeding $25 \mathrm{~cm}$ was increasingly adopted in response to encouragement for increased sugar beet production. For beets, tillage depth was significantly relevant to water and soil conservation, because as soil porosity increased, more water was retained in tilled layer. However, the increased porosity and available water also stimulated the mineralization of soil organic matter. Burying crop stubble to a depth of $12 \mathrm{~cm}$ also enhanced decomposition such that nearly all the residue was mineralized during the 18 month fallow period, whereas only $33 \%$ of residue was decomposed when left on the soil surface [79].

Tillage has been an integral part of agriculture for several hundred years, although the standards by which the process was evaluated declined following the two world wars and as a consequence of land redistribution and privatization. Farmers failed to recognize the importance soil tillage research but they were quick to respond to changes in economic conditions.

Excessive tillage cannot be directly linked to any particular time period [17,80] or economic condition, although economizing under the force of necessity has always been a typical human response to periods of economic difficulty. Therefore, farmer attitudes with respect to rationalizing tillage could, in retrospect, be explained by shortage of capital. Often it was easier to follow traditional methods than to invest in new equipment, fertilizers, or pesticides. Simple tradition may also be an explanation for farmer aversion to new production methods even though soil deterioration symptoms that originated due to long-term traditional tillage [81] are becoming increasingly abundant.

Other authors have stated that without remedying the condition of the soils, it will be nearly impossible to achieve adoption of new techniques introduced into the CASSE region. This conclusion is supported 
by soil protection research which has been a key subject for decades. Only now are the results achieved so far being taken into account for development and application of new cultivation practices [82].

Table 4 lists several different methods of soil protection with the first of them coming from work by North-American researchers [83]. The different methods of soil protection have been developed and are being conducted in parallel with no-till experiments within areas exposed to water and/or wind erosion [84]. Currently, there is growing interest in other soil conservation techniques (e.g., till-plant, mulch-till, and strip-till), to some extent perhaps as a consequence of increasing climate threats.

One of the new management strategies, known as conservation agriculture (CA) requires adoption of supplemental agricultural practices that minimize degradation of the soil organic matter and soil structure, protect against soil erosion and degradation, and preserve soil biodiversity [85]. The first step toward adoption of CA involves recognition of the risks (i.e., wrong practices, bad habits, poor soil quality, extreme climate phenomena) and the desire for improvement, while the second step involves improvement or conservation of soil quality in harmony with ecological conditions, mechanization and the farm management conditions.

Table 4. Soil tillage trends, objectives and realization in the CASEE region.

\begin{tabular}{|c|c|c|c|c|}
\hline \multirow{2}{*}{ Trends } & \multirow{2}{*}{$\begin{array}{c}\text { Time and place } \\
\text { of developing }\end{array}$} & \multirow{2}{*}{ Aims of the system } & \multicolumn{2}{|c|}{ In the CASEE region } \\
\hline & & & appearance & realization \\
\hline Minimum tillage & 1950s (USA) & $\begin{array}{l}\text { cutting tillage depth, } \\
\text { passes and costs }\end{array}$ & mid-1970s & $\begin{array}{l}\text { reduced constraint } \\
\text { e.g., disk tillage }\end{array}$ \\
\hline Reduced tillage & 1960s (USA) & $\begin{array}{l}\text { cutting tillage passes } \\
\text { and costs }\end{array}$ & $\mathrm{mid} / \mathrm{end}-1970 \mathrm{~s}$ & $\begin{array}{l}\text { tool/element } \\
\text { combination }\end{array}$ \\
\hline $\begin{array}{l}\text { Conservation } \\
\text { tillage }\end{array}$ & 1960s (USA) & $\begin{array}{l}\text { effectual soil preserving } \\
\text { by surface cover }(\geq 30 \%) \\
\text { after sowing }\end{array}$ & $\begin{array}{l}\text { end-1980s, first } \\
\text { years of the } 2000 \mathrm{~s}\end{array}$ & $\begin{array}{l}\text { surface cover after } \\
\text { stubble tillage and } \\
\text { after some types of } \\
\text { primary tillage }\end{array}$ \\
\hline No-till & 1950s (USA) & $\begin{array}{l}\text { soil and water preserving by } \\
\text { minimized soil disturbance }\end{array}$ & from the $1960 \mathrm{~s}$ & $\begin{array}{l}\text { problems in the } \\
\text { first years limited } \\
\text { the interests }\end{array}$ \\
\hline Mulch-till & 1980s (USA) & $\begin{array}{l}\text { soil and water preserving by } \\
\text { whole surface disturbance } \\
\text { and by fair surface cover }\end{array}$ & $\begin{array}{l}\text { mid-1980s, first } \\
\text { years of the } 2000 \mathrm{~s}\end{array}$ & $\begin{array}{l}\text { good: by tine, by } \\
\text { loosening, risky: } \\
\text { by disking }\end{array}$ \\
\hline Ridge-till & 1980s (USA) & $\begin{array}{l}\text { soil and water preserving in } \\
\text { sloped fields }\end{array}$ & $1990 \mathrm{~s}$ & in experiments only \\
\hline Strip-till-1st & 1970s (USA) & clean sowing strips, covered & $1990 \mathrm{~s}$ & tepid interest \\
\hline Strip-till-2nd & 2000s (USA) & $\begin{array}{l}\text { inter rows - reducing tillage } \\
\text { intervention and costs; } \\
\text { improved by satellite } \\
\text { guidance and automatic } \\
\text { positioning }\end{array}$ & $2010 \mathrm{~s}$ & $\begin{array}{l}\text { field trials with hope } \\
\text { of the extending }\end{array}$ \\
\hline $\begin{array}{l}\text { Climate } \\
\text { mitigating }\end{array}$ & $\begin{array}{l}\text { mid-1990s } \\
\text { (Europe) }\end{array}$ & $\begin{array}{l}\text { all systems are adaptable to } \\
\text { site and climate conditions }\end{array}$ & $\begin{array}{l}\text { first years of the } \\
2000 \mathrm{~s}\end{array}$ & $\begin{array}{l}\text { step by step, } \\
\text { however time presses }\end{array}$ \\
\hline
\end{tabular}


Twelve factors have been selected to outline the fundamental requirements of sustainable soil tillage [86,87]. These are:

(1) Avoiding farming- and tillage-induced soil damage, including occurrence and extension of soil compaction, degradation of soil structure, water and wind erosion, high $\mathrm{CO}_{2}$ emission, and loss of organic material.

(2) Maintaining soil moisture transport by improving infiltration and storage during wet periods and decreasing moisture loss during dry and average seasons. As indicated by Avci [52], crop residue cover is very important for meeting this requirement because it reduces wind speed, prevents sunlight from penetrating the soil surface and increasing evaporation, and if standing traps snow for extra soil moisture.

(3) Preserving soil organic matter to increase water-holding capacity, structure stability, loading capacity, and workability while decreasing soil compactibility and vulnerability. Again, leaving plant residue on soil surface will provide erosion control and lead to an increase in soil organic matter content.

(4) Managing stubble residues by applying harvest and tillage techniques that leave mulch cover. Covering the surface for as long as possible after harvest will help preserve soil structure, moisture and mitigate heat and rainfall stresses outside the growing season. Surface cover, particularly with small-stemmed crop residues such as wheat or barley, creates a friction with the wind and effectively reduce the erosion [52].

(5) Recycling stubble residues to increase soil organic matter, promote favorable biological activity, and improve workability through the mellowing processes.

(6)Optimizing machinery (i.e., tractor selection, tool mass, running gear, working speed) and arable site factors to reduce energy consumption and decrease environmental load.

(7) Minimizing soil loading from stubble to sowing phases.

(8) Applying optimal crop sequences to reduce fertilizer needs and improve soil biological activity.

(9) Maintaining infiltration, storage capacity, and aggregation on irrigated soils.

(10) Applying tools without creating tillage pans, particularly in wet soils.

(11) Assessing possible risks prior to establishment of new tillage and sowing systems. Soil condition assessment will have greater importance before tillage interventions, in crop stands and after sowing.

(12) Selecting the most adaptable soil conservation methods that conform to site and crop production requirements.

Table 5 provides a summary of tillage and sowing methods that appear to be adaptable to CASEE soil conditions. Overall, mulch-till with subsoiling or tine tillage appear to be indispensable for maintaining stability and reliability of cropping in extreme seasons. Tine tillage is also recommended for gently mixing the upper $(0-30 \mathrm{~cm})$ layer of soil after three to four years of strip-till. Mulch-till with disking should only be applied if deeper soil layers are in good condition, and the soil is dry. Composting tillage shows similar advantages and risks. 
Table 5. Experiences in soil conservation solutions in the CASEE region.

\begin{tabular}{|c|c|c|c|c|}
\hline System/method & Method & Main advantages & Main considerations & First adoption \\
\hline Mulch-till & Subsoiling & $\begin{array}{l}\text { Deep rooting, less } \\
\text { climate dependence } \\
\text { due to improved } \\
\text { water transport }\end{array}$ & $\begin{array}{l}\text { Weed infestation } \\
\text { in the first years }\end{array}$ & $\begin{array}{l}\text {-mid 1980s } \\
\text {-from the } 2000 \mathrm{~s}\end{array}$ \\
\hline Mulch-till & Tine & $\begin{array}{l}\text { Soil structure } \\
\text { preserving and } \\
\text { improvement, less } \\
\text { dependence on soil } \\
\text { water content }\end{array}$ & $\begin{array}{l}\text { Same diseases, } \\
\text { weed infestation } \\
\text { in the first years }\end{array}$ & $\begin{array}{l}\text {-mid } 1980 \mathrm{~s} \\
\text {-from the } 2000 \mathrm{~s}\end{array}$ \\
\hline Mulch-till & Disking & $\begin{array}{l}\text { Saving time } \\
\text { and energy }\end{array}$ & $\begin{array}{l}\text { Shallow loosened } \\
\text { layer, higher climate } \\
\text { dependence }\end{array}$ & -from the $1980 \mathrm{~s}$ \\
\hline Till-plant & $\begin{array}{l}\text { Shallow }(2-5 \mathrm{~cm}) \\
\text { or deeper } \\
(810-15 \mathrm{~cm})\end{array}$ & $\begin{array}{l}\text { Saving time and } \\
\text { energy }\end{array}$ & State of the root zone & -from the $2010 \mathrm{~s}$ \\
\hline No-till & $\begin{array}{l}\text { Continuous or } \\
\text { short term }\end{array}$ & $\begin{array}{l}\text { Saving time and } \\
\text { energy }\end{array}$ & $\begin{array}{l}\text { Continuous: long-term } \\
\text { soil conversion; } \\
\text { occasional: soil } \\
\text { water content }\end{array}$ & $\begin{array}{l}-1960 s, 1990 \mathrm{~s} \\
-2010 \mathrm{~s}\end{array}$ \\
\hline \multirow[t]{2}{*}{ Strip-till } & $\begin{array}{l}\text { Depth is varied } \\
\text { for crops }\end{array}$ & $\begin{array}{l}\text { Loosened soil to the } \\
\text { created depth, } \\
\text { saving time and } \\
\text { energy }\end{array}$ & $\begin{array}{l}\text { Uncrushed maize } \\
\text { stalks (good habitat } \\
\text { to E. corn borer) }\end{array}$ & -from the $2010 \mathrm{~s}$ \\
\hline & Twin-row sowing & $\begin{array}{l}\text { Deep rooting in } \\
\text { subsoiled variant }\end{array}$ & $\begin{array}{l}\text { Endeavors to } \\
\text { optimizing crop } \\
\text { root development } \\
\text { and placement }\end{array}$ & $\begin{array}{l}\text {-Kolbai, 1956, } \\
\text { Hungary } \\
\text {-2010s (USA) }\end{array}$ \\
\hline $\begin{array}{l}\text { Composting } \\
\text { tillage }\end{array}$ & All crops & $\begin{array}{l}\text { Soil structure } \\
\text { preserving and } \\
\text { improvement } \\
\end{array}$ & $\begin{array}{l}\text { Depth of the } \\
\text { loosened layer }\end{array}$ & $\begin{array}{l}\text {-from the } 2010 \\
\text { (Slovenia) }\end{array}$ \\
\hline
\end{tabular}

Strip-till is suitable for mid-technology farming because it can create a good soil state with only a small amount of tillage. No-till is a special cropping method that minimizes soil disturbance but requires modern machinery, sound experience, frequent technology updates, and adjustments to the site, year and crop being grown. The risks associated with conservation farming can be minimized through planning and progressive management. Therefore, considering the disadvantages of intensive farming and related costs, direct seeding becomes more viable and may have fewer plant production problems for Turkish farmers $[25,52,88]$.

\section{Conclusions}

Soil characteristics are directly or indirectly altered and their capacity to function is either limited or enhanced by humans. Since degradation of lands cannot solely be accounted for by physical or 
technical causes, social and political dynamics along with any activities that threaten soil quality in CASEE countries should be controlled by laws and regulations. Environmental awareness and improved socio-economic status of people in rural areas are also important incentives for encouraging farmer adoption of new conservation and agricultural practices. The negative effects of unfavorable agricultural management on the environment generally originate at the single farm level. Therefore adaptation of tools for improving soil quality is needed at this level. The main limitations and uncertainty regarding soil sustainability can often be traced back the economic situation which causes fluctuations in agricultural activities, including soil remediation.

Most soils have the potential to resist degradation processes to some extent. Therefore, the rate of degradation can be efficiently decreased and their unfavorable consequences can be at least moderated by maintaining and continuing to use appropriate land management and water conservation practices.

Finally, we conclude that low productivity soils in CASEE countries and elsewhere around the world can be eliminated by implementing site-specific tillage and intensive crop production systems that improve low organic matter soils by minimizing conventional tillage, residue removal, soil compaction, water and wind erosion.

\section{Acknowledgments}

The authors would like to thank Douglas L. Karlen for the useful comments and the English language review of the Manuscript.

\section{Author Contributions}

All authors contributed equally to this work. All authors read and approved the final manuscript.

\section{Conflicts of Interest}

The authors declare no conflict of interest.

\section{References}

1. Debicki, R. State of the Land Degradation in Central and Eastern Europe: Proceedings of the Workshop on Land Degradation/Desertification in Central and Eastern Europe in the Context of the UNCCD. Available online: http://www.unccd.int/Lists/SiteDocumentLibrary/Regions/CEE /meetings/regional/brussels05_2000/proceedings.pdf (accessed on 8 May 2000).

2. Andronikov, S. The present status of the soil environment in Russia. In Soil Quality, Sustainable Agriculture and Environmental Security in Central and Eastern Europe; Springer Netherlands: Heidelberg, Germany, 2000; pp. 87-95.

3. Blum, W.E.H. Characterisation of soil degradation risk: An overview. In Threats to Soil Quality in Europe; Tóth, G., Montanarella, L., Rusco, E., Eds.; EUR 23438 EN; Publications Office: Luxembourg, 2008; pp. 5-10.

4. Ozturk, M.; Ozcelik, H.; Sakcali, M.S.; Guvensen, A. Land degradation problems in the Euphrates basin, Turkey. Environews 2004, 10, 7-9. 
5. Tóth, G. Soil quality in the European Union. In Threats to soil quality in Europe; Tóth, G., Montanarella, L., Rusco, E., Eds.; EUR 23438 EN; Publications Office: Luxembourg, 2008; pp. 11-20.

6. Lloyd, S. Ancient Turkey: A Traveller's History of Anatolia; University of California Press: Oakland, CA, USA, 1989.

7. Montgomery, D. Dirt: The Erosion of Civilizations; University California Press: Los Angeles, CA, USA, 2007.

8. Doran, J.W.; Parkin, T.B. Defining and assessing soil quality. In Defining Soil Quality for a Sustainable Environment; Doran, J.W., Coleman, D.C., Bezdicek, D.F., Sterwart, B.A., Eds.; SSSA Special Publication; Soil Science Society of Amer Madison: Madison, WI, USA, 1994; pp. 3-21.

9. Gentile, A.R. Soil degradation in Europe. In Soil Degradation in Central and Eastern Europe: The Assessment of the Status of Human-induced Degradation; United Nations Environment Programme (UNEP), and ISRIC - World Soil Information: Wageningen, The Netherland, 2000; pp. 68-89.

10. Corwin, D.L.; Kaffka, S.R.; Hopmans, J.W.; Mori, Y.; van Groenigen, J.W.; van Kessel, C.; Oster, J.D. Assessment and field-scale mapping of soil quality properties of a saline-sodic soil. Geoderma 2003, 114, 231-259.

11. Várallyay, G. Soil degradation processes and extreme soil moisture regime as environmental problems in the Carpathian Basin. Agrokémia és Talajtan 2006, 55, 9-18.

12. Gajri, P.R.; Arora V.K.; Prihar S.S. Tillage for Sustainable Cropping; Food Products Press: New York, NY, USA, 2002.

13. Balteanu, D.; Dragota, C.S.; Popovici, A.; Dumitrascu, M.; Kucsicsa, G.; Grigorescu, I. Land use and crop dynamics related to climate change signals during the post-communist period in the south Oltenia, Romania. Proc. Rom. Acad. 2013, 15, 265-278.

14. Halbac, C.Z.R. Changes in agricultural water demands for western Romania. In Proceedings of the 42nd International Symposium on Agricultural Engineering, Opatija, Croatia, 25-28 February 2014; pp. 35-46.

15. Özgöz, E.; Gunal, H.; Acir, N.; Gokmen, F.; Birol, M.; Budak, M. Soil quality and spatial variability assessment of land use effects in a typic haplustoll. Land Degred. Dev. 2013, 24, 277-286.

16. Birkás, M.; Antal, J.; Dorogi, I. Conventional and reduced tillage in Hungary-A review. Soil Tillage Res. 1989, 13, 233-252.

17. Birkás, M.; Antos, G.; Neményi, M.; Szemők, A. Environmentally-sound adaptable tillage. Acta Agron. Hung. 2008, 57, 191-194.

18. McCarthy, J.R.; Pfost, D.L.; Currence, H.D. Direct Planting and Residue Management to Reduce Soil Erosion; Agricultural Publication G1650: Columbia, MO, USA, 1993.

19. Fallahi, F.; Raoufat, M.H. Row-crop planter attachments in a direct planting system: A comparative study. Soil Tillage Res. 2008, 98, 27-34.

20. Chastin, T.G.; Ward, J.K.; Wysocki, D.J. Stand establishment response of soft winter wheat to seed bed residue and seed size. Crop Sci. 1995, 35, 213-218.

21. Derpsch, R.; Florentin, M.; Moriya, K. The laws of diminishing yields in the tropics. In Proceedings of the 17th ISTRO Conference, Kiel, Germany, 28 August-3 September 2006; International Soil Tillage Research Organization: Kiel, Germany, 2006. 
22. Gus, P. The influence of Soil Tillage on yield and on some soil characteristics. In Proceeding of the Alternatives in Soil Tillage Symposium, Cluj-Napoca, Romania, 9-10 October 1997; pp. 151-155.

23. Korucu, T.; Arslan, S. Effects of direct and conventional planting on soil properties and yield characteristics of second crop maize. Agric. Sci. 2009, 15, 157-165.

24. Arslan S.; Korucu, T. Conventional and conservation tillage systems performance on two different soils in Turkey. In Proceeding of the 10th International Agricultural Engineering Conference, Bangkok, Thailand, 7-10 December 2009; Salokhe, V.M., Soni, P., Eds.; Asian Association for Agricultural Engineering: Klong Luang, Thailand, 2009.

25. Yalçın, H.; Çakır, E. Tillage effects and energy efficiencies of subsoiling and direct seeding in light soil and yield of second crop corn for tillage in western Turkey. Soil Tillage Res. 2006, 90, 250-255.

26. Topa, D.; Ailincai, C.; Raus, L.; Cara, M.; Jitareanu, G. Tillage effects on soil structure and grain yield of maize. Lucrări Ştiinţifice 2012, 55, 237-240.

27. Mihovsky, T.; Pachev, I. Reduced tillage practices. Available online: http://www.bjbabe.ro/ reduced-tillage-practices-3/ (accessed on 10 December 2014).

28. Houšková, B.; Montanarella, L. The natural susceptibility of European soils to compaction. In Threats to Soil Quality in Europe EUR; Tóth, G., Montanarella, L., Rusco, E., Eds.; EUR 23438 EN; Publications Office: Luxembourg, 2008; pp. 23-35.

29. Wysocki, D. Measuring residue cover. Pacific Northwest (PNW) Conservation Tillage Handbook Series. Available online: http://pnwsteep.wsu.edu/tillagehandbook/chapter3/030988.htm (accessed on 10 August 2008).

30. Mc Kenney, D.J.; Wang, S.W.; Drury, C.F.; Findlay, I. Denitrification and mineralization in soil emended with legume, grass and corn residues. Soil Sci. Soc. Am. J. 1993, 57, 1013-1020.

31. Jones, R.J.; Hiederer, R.; Rusco, E.; Loveland, P.J.; Montanarella, L. The Map of Organic Carbon in Topsoils in Europe; Office for Official Publications of the European Communitie: Luxembourg, 2003.

32. European Conservation Agricultural Federation. Conservation Agriculture in Europe: Environmental, Economic and EU Policy Perspectives; European Conservation Agricultural Federation: Brussels, Belgium, 1999.

33. Lal, R. Carbon sequestration in dryland ecosystems of West Asia and North Africa. Land Degrad. Dev. 2002, 13, 45-59.

34. Lal, R. Soil quality impacts of residue removal for bioethanol production. Soil Tillage Res. 2009, 102, 233-241.

35. TurkStat. Statistical Yearbook of Turkey, 2001; Turkish Statistical Institute: Ankara, Turkey, 2009.

36. Çelik, I. Land-use effects on organic matter and physical properties of soil in a southern Mediterranean highland of Turkey. Soil Tillage Res. 2005, 83, 270-277.

37. Montanarella, L.; Olazabal, C.; Selvaradjou, S.K. Reports of the Technical Working Groups Established under the Thematic Strategy for Soil Protection; Office for Official Publications of the European Communities: Luxembourg, 2004. 
38. Bireescu, G.; Ailincai, C.; Raus, L.; Bireescu, L. Studding the impacts of technological measures on the biological activity of pluvial eroded soils. In Land Degradation and Desertification: Assessment, Mitigation and Remediation; Zdruli, P., Pagliai, M., Kapur, S., Cano, A.F., Eds.; Springer Netherlands: Heidelberg, Germany, 2010; pp. 529-547.

39. Bescansa, P.; Imaz, M.J.; Virto, I.; Enrique, A.; Hoogmoed, W.B. Soil water retention as affected by tillage and residue management in semiarid Spain. Soil Tillage Res. 2006, 87, 19-27.

40. Korucu, T.; Arslan, S.; Günal, H.; Şahin, M. Spatial and temporal variation of soil moisture content and penetration resistance as affected by post harvest period and stubble burning of wheat. Fresenius Environ. Bull. 2009, 18, 1736-1747.

41. Valzano, F.P.; Greene, R.S.B.; Murphy, B.W. Direct effects of stubble burning on soil hydraulic and physical properties in direct drill tillage. Soil Tillage Res. 1997, 42, 209-219.

42. Are, K.S.; Oluwatosin, G.A.; Adeyolanu, O.D.; Oke, A.O. Slash and burn effect on soil quality of an Alfisol: Soil physical properties. Soil Tillage Res. 2008, 103, 4-10.

43. Food and Agriculture Organization of the United Nations. Manual on Integrated Soil Management and Conservation Practices (FAO Land and Water Bulletin); Food and Agriculture Organization of the United Nations: Rome, Italy, 2000.

44. Cabeda, M.S.V. Degradação física e erosão. In I Simpósio de Manejo do solo e Plantio Direito no sul do Brasil e III Simpósio de Conservação de Solos do Planalto; Passo Fundo: Univerdidade de Passo, Fundo, Brasil, 1984.

45. IRENA indicator 23-Soil erosion. Available online: http://epp.eurostat.ec.europa.eu/ statistics_explained/index.php/Agri-environmental_indicator_-_soil_erosion (accessed on 25 September 2014).

46. Blum, W.E. The challenge of soil protection in Europe. Environ. Conserv. 1990, 17, 72-74.

47. Sauerborn, P.; Klein, A.; Botschek, J.; Skowronek, A. Future rainfall erosivity derived from large-scale climate models-Methods and scenarios for a humid region. Geoderma 1999, 93, 269-276.

48. Motoc, M.; Ionita I.; Nistor D.; Vatau A. Soil Erosion Control in Romania; Regional Environmental Centre: Budapest, Hungary, 1992.

49. Mircea, S.; Petrescu, N.; Musat, M.; Radu, A.; Sarbu, N. Soil erosion and conservation in Romania-Some figures, facts and its impact on environment. Ann. Food Sci. Technol. 2010, 11, $105-110$.

50. Kapur, S.; Akça, E.; Kapur, B.; Öztürk, A. Migration: An irreversible impact of land degradation in Turkey. In Desertification in the Mediterranean Region; Springer Netherlands: Heidelberg, Germany, 2006; pp. 291-301.

51. Aykas, E.; Çakır, E.; Yalçın, H.; Çelik, A.; Okur, B.; Nemli, Y. Koruyucu toprak işleme, doğrudan ekim ve türkiye'deki uygulamalari. In Proceedings of the Ziraat Mühendisliği VII Teknik Kongresi, 11-15 Ocak 2010; pp. 269-292.

52. Avci, M. Conservation tillage in Turkish dryland research. In Sustainable Agriculture; Springer Netherlands: Heidelberg, Germany, 2011; pp. 351-361.

53. Oldeman, L.R.; Hakkeling, R.T.A.; Sombroeck, W.G. World Map of the Status of Human-Induced Soil Degradation: An Explanatory Note; United Nations Environment Programme and ISRIC_-World Soil Information: Wageningen, The Netherlands, 1991. 
54. Khan, T.O. Soil Degradation, Conservation and Remediation; Springer Netherlands: Heidelberg, Germany, 2014; p. 237.

55. Allen, J.C. Soil response to forest clearing in the United States and the tropics: Geological and biological factors. Biotropica 1985, 17, 15-27.

56. Håkansson, I. Subsoil compaction caused by heavy vehicles: A long-term threat to soil productivity. Soil Tillage Res. 1994, 29, 105-110.

57. Fabiola, N.; Giarola, B.; da Silva, A.P.; Imhoff, S.; Dexter, A.R. Contribution of natural soil compaction on hardsetting behavior. Geoderma 2003, 113, 95-108.

58. Çarman, K. Compaction characteristics of towed wheels on clay loam in a soil bin. Soil Tillage Res. 2002, 65, 37-43.

59. Hebert, J. About the problems of structure in relation to soil degradation. In Soil Degradation: Proceedings of the Land Use Seminar on Soil Degradation Wageningen 13-15 October 1980; Boels, D., Davies, D.B., Johnston, A.E., Eds.; CRC Press: Boca Raton, FL, USA, 1982.

60. European Environment Agency. Europe's Environment: The Dobris Assessment; Publications of the European Communities: Luxembourg, 1995.

61. Van den Akker, J.J.H.; Schjonning, P. Subsoil compaction and ways to prevent it. In Managing Soil Quality: Challenges in Modern Agriculture; Schjonning, P., Elmhlot, S., Christensen, B.T., Eds.; CABI: Wallingford, UK, 2004.

62. Çullu, M.A.; Aydemir, S.; Qadir, M.; Almaca, A.; Öztürkmen, A.R.; Bilgic, A.; Ăgca, N. Implication of groundwater fluctuation on the seasonal salt dynamic in the Harran Plain, south-eastern Turkey. Irrig. Drain. 2010, 59, 465-476.

63. Kendirli, B.; Cakmak, B.; Ucar, Y. Salinity in the Southeastern Anatolia Project (GAP), Turkey. Issues and Options. Irrig. Drain. 2005, 54,115-122.

64. Abrol, I.P.; Yadav, J.S.P.; Massoud, F.I. Salt-Affected Soils and Their Management (No. 39); Food and Agriculture Organization of the United Nations: Rome, Italy, 1988.

65. Frizen, D. Managing saline soils in North Dakota. NDSU Extension Service, Fargo, ND 58105 Available online: http://www.ag.ndsu.edu/pubs/plantsci/soilfert/sf1087.pdf (accessed on 13 January 2015).

66. Halbac, C.Z.R. Romania's Western Part (Timis County) Facing Climatic Changes; Lambert Academic Publishing: Saarbrücken, Germany, 2010.

67. Terelak, H.; Stuczynski, T.; Piotrowska, M. Heavy metals in agricultural soils in Poland. Pol. J. Soil Sci. 1997, 2, 35-42.

68. Murányi, A. Quality and contamination of agricultural soils in Hungary as indicated by environmental monitoring and risk assessment. In Soil Quality, Sustainable Agriculture and Environmental Security in Central and Eastern Europe; Springer Netherlands: Heidelberg, Germany, 2000; pp. 61-77.

69. Podlešáková, E.; Nemecek, J. Contamination and degradation of soils in the Czech Republic-Contemporary and future state. In Soil Quality, Sustainable Agriculture and Environmental Security in Central and Eastern Europe; Springer Netherlands: Heidelberg, Germany, 2000; pp. 79-86.

70. Ministry of Waters, Forests and Environmental Protection of Romania (2003); Environment Protection Strategy: Romania, Bucharest, 2003; p. 178. 
71. Soil Sealing. Available online: http://globalsoilweek.org/wp-content/uploads/2013/10/GSW factsheet_Sealing_en.pdf(accessed on 3 November 2014).

72. Dinç, U.; Akca, E.; Dinç, D.M.; Özden, D.M.; Tekinsoy, P.; Alagöz, H.A.; Kapur, S. Soil sealing: The permanent loss of soil and its impacts on land use. In First MEDRAP Workshop on Sustainable Management of Soil and Water Resources-Greece/European Union Concerted Action to Support the Northern Mediterranean RAP; University of Sassari: Athens, Greece, 2001; pp. 18-19.

73. Haktanir, K.; Karaca, A.; Omar, S.M. The prospects of the impact of desertification on Turkey, Lebanon, Syria and Iraq. In Environmental Challenges in the Mediterranean 2000-2050; Springer Netherlands: Heidelberg, Germany, 2004; pp. 139-154.

74. Birkás, M. Tillage, impacts on soil and environment. In Encyclopedia of Agrophysics; Glinski, J., Horabik, J., Lipiec, J., Eds.; Springer: Dordrecht, The Netherlands, 2011; pp. 903-906.

75. Turk, A.; Mihelič, R. Wheat straw decomposition, N-mineralization and microbial biomass after 5 years of conservation tillage in Gleysol field. Acta Agric. Slov. 2013, 101, 69-75.

76. Korucu, T.; Kirişci, V.; Görücü, S. Korumalı toprak işleme ve Türkiyedeki uygulamaları. In Proceedings of the Tarımsal Mekanizasyon 18. Ulusal Kongresi, Tekirdağ, Türkiye, 17-18 Eylül 1998. (In Turkish)

77. Kalmár, T.; Pósa, B.; Sallai, A.; Csorba, S.; Birkás, M. Soil quality problems induced byextreme climate conditions. Növénytermelés 2013, 62, 209-212.

78. Schertz, D.L. Conservation tillage: An analyis of acreage projections in the United States. J. Soil Water Conserv. 1988, 43, 256-258.

79. Özbek, H.; Dinç, U.; Güzel, N.; Kapur, S. Çukurova Bölgesinde anız Yakmanın Topragın Fiziksel ve Kimyasal Özellikleri Üzerine Etkisi; Toag No: 182; Tubitak: Ankara, Turkey, 1976; pp. 3-5. (In Turkish)

80. Jug, D.; Birkás, M.; Šeremešić, S.; Stipešević, B.; Jug, I.; Žugeć, I.; Djalović, I. Status and perspective of soil tillage in South-East Europe. In Proceedings of the 1st International Scientific Symposium on Soil Tillage-Open Approach, Osijek, Croatia, 9-11 September 2010; Jug, I., Vukadinović, V., Eds.; CROSTRO: Osijek, Croatia; pp. 50-64.

81. Kovačević, D.; Lazić, B. Modern trends in the development of agriculture and demands on plant breeding and soil management. Genetika 2012, 44, 201-216.

82. Spoljar, A.; Kisic, I.; Birkás, M.; Gunjaca, J.; Kvaternjak, I. Influence of crop rotation, liming and green manuring on soil properties and yields. J. Environ. Prot. Ecol. 2011, 12, 54-69.

83. Allen, R.R.; Fenster, C.R. Stubble-mulch equipment for soil and water conservation in the Great Plains. J. Soil Water Conserv. 1986, 41, 11-16.

84. Kisić, I.; Bašić, F.; Nestroy, O.; Mesić, M.; Butorac, A. Soil erosion under different tillage methods in central Croatia. Die Bodenkultur 2003, 53, 197-204.

85. Agri-environmental indicator-tillage practices. Available online: http://epp.eurostat.ec.europa.eu/ statistics_explained/index.php/Agri-environmental_indicator_-_tillage_practices (accessed on 02 December 2014).

86. Bašić, F. Land degradation in Croatia. In Land Degradation; Jones, R.J.A., Montanarella, L., Eds.; Publications of the European Communities: Luxembourg, 2003; pp. 165-176. 
87. Birkás, M.; Mesić, M. Impact of tillage and fertilization on probable climate threats in Hungary and Croatia, soil vulnerability and protection. In Hungarian-Croatian Intergovernmental S\&T Cooperation 2010-2011; Szent István Egyetemi Kiadó: Gödöllő, Magyarország, 2012; p. 186.

88. Rasmussen, K.J. Impact of ploughless soil tillage on yield and soil quality: A Scandinavian review. Soil Tillage Res. 1999, 53, 3-14.

(C) 2015 by the authors; licensee MDPI, Basel, Switzerland. This article is an open access article distributed under the terms and conditions of the Creative Commons Attribution license (http://creativecommons.org/licenses/by/4.0/). 